\title{
NEW SPECIES AND NEW RECORD OF ANTHOMEDUSAE FROM SOUTHERN BRAZIL
}

(Received in 18/3/66)

\author{
M. VANNUCCI \\ $\&$ \\ M. G. B. Soares Moreira \\ Instituto Oceanográfico da Universidade de São Paulo
}

\begin{abstract}
SYNOPSIS
A new species of Hydromedusa belonging to the genus Octocanna Haeckel 1879 , here revived, is described from the coastal waters off Santos. The new species belongs to the family Phialuciidae, it is named Octocanna haeckeli $\mathrm{sp} . \mathrm{n}$. and differs from the other two species of the genus in being smaller, in having a high dome shaped umbrella, four tentacles, eight bulbs and eight marginal vesicles at sexual maturity. The genus Octocanna is here revived for Phialuciidae with eight radial canals, eight gonads, four or more tentacles and never more than four lips.

The genus Octophialucium Kramp 1955 is considered valid for Phialuciidae with eight radial canals, eight gonads and eight lips. In the same series of samples, some specimens of Octophialucium bigelowi Kramp 1955 were taken which are very similar to Octocanna haeckeli but have eight lips, eight tentacles, rudimentary bulbs and a larger number of marginal vesicles at sexual maturity, which is reached at approximately the same umbrella size. The two similar species were taken in the same water mass at approximately the same time of the same year.
\end{abstract}

Octocanna haeckeli sp. n. -

(Figs. 1, 2, 3, 4, 8, 9, 10)

Material - In plankton samples taken in past years in the coastal area of the State of São Paulo, southern Brazil, there were a few specimens of a small globular medusa that appeared to belong to the genus Octophialucium Kramp 1955, but had only four lips as described by HAECKEL (1879) in his definition of the genus Octocanna. The specimens were mailed to Prof. Kramp but most unfortunately were lost. Three more specimens were taken recently. Twio were taken at fixed station $n .^{\circ} \quad l$ at $24^{\circ} 04.5^{\prime} \mathrm{S}-46^{\circ} 14.7^{\prime} \mathrm{W}, \mathrm{SE}$ of Santos, in 1960. The specimens are preserved in $4 \%$ neutral formalin, the holotype is deposited under $n .^{\circ} 475$ at the Zoological Museum of São Paulo (Departamento de Zoologia da Secretaria da Agricultura do Estado de São Paulo). One more mature specimen was also taken off Santos.

One of the specimens was found in Sample E316 taken with Hensen net May 9, 1960, over $28 \mathrm{~m}$ depth, vertical haul from $25 \mathrm{~m}$ to the surface. The salinity range was $33.61-35.50 \%$ and the temperature range $23.3-24.0^{\circ} \mathrm{C}$. The other spe-

Publ, n² 235 do Inst. Ocean, da USP. cimen comes from sample E344 taken June 6, 1960 with a Clarke-Bumpus sampler towed in the deeper layer in the shelf water mass with $35.14 \%$ salinity and $21.9^{\circ} \mathrm{C}$ temperature. Of the third specimen taken in the same area we have no environmental data.

Description - The diagnosis of the genus Octocanna Haeckel 1879 is as follows: "Aequoride mit acht einfachen, unverästelten Radial-Canälen (4 perradialen und 4 interradialen), welche getrennt aus der Magen-Peripherie entspringen. Magen weit und flach, ohne Magenstiel. Mund mit 4 grossen Mundlappen".

The present species agrees with the diagnosis of the genus as given by HAECKel. The specific characters of the new species are as follows: The umbrella is about as wide as high, globular, jelly very thick. Eight rather narrow radial canals run straight to the umbrella margin. The stomach is of regular size and bears four very large perradial lips capable of great extension; one of the specimens shows a wide open mouth while the others have a closed mouth showing the extent of the lips when folded. The manubrium does not extend beyond the 
umbrella margin. The subumbrella cavity occupies about half or less than half of the umbrella height. The umbrella margin bears eight bulbs, four large hollow perradial ones bearing a tentacle each and four smaller interradial ones devoid of tentacles. Both bulbs and tentacles are hollow. There are eight marginal vesicles, one between two successive bulbs. In one of the specimens there are nine marginal vesicles. There are eight hollow gonads at the distal end of the proximal third of each radial canal. As the gonads mature they tend to extend distally. Excretory pores are present, on very small adradial papillae.

The new species is called Octocanna haeckeli in honour of E. HAECKEL.

Discussion - HAECKEL described two species of the genus Octocanna. O. octonema, taken in March 1873 in the Red Sea, on the coast of the Sinai peninsula and $O$. polynema taken in the Indian Ocean. $O$. octonema is smaller and differently shaped, it is $10 \mathrm{~mm}$ wide by $5 \mathrm{~mm}$ high, the gonads are linear, it shows eight tentacles and 16 marginal vesicles, two between adjoining tentacles. $O$. poly. nema, taken near Singapore, is $15 \mathrm{~mm}$ wide and $5 \mathrm{~mm}$ high, has 32 tentacles and $60-80$ marginal vesicles, each with two concretions. Octocanna haeckeli has only 8 marginal vesicles, four tentacles and four bulbs.

Kramp (1955, 1959) summarized all the descriptions of specimens posterior to Haeckel's Monograph and showed that most of them had since been "erroneously" referred to the genus Octocanna. Among other important characters, the authors refer to the presence of eight lips instead of four. KRAMP created the genus Octophialucium for such eight lipped species belonging to the family Phialuciidae. KRAMP clearly states that "if the mouth of Haeckel's medusae.... really had only four lips, they cannot be congeneric with any of the species described up to now and without further consideration referred to Octocanna. I find it more reasonable to regard both species as obsolete and introduce a new generic name for the various medusae with (normally) eight simple radial canals and eight mouth lips..." (Kramp, 1955, p. 259). Having now found specimens which unquestionably have four lips and otherwise agree with Haeckel's definition of Octocanna, this genus must be revived.

We do not believe that the four lipped medusae are young developmental stages of the fully developed specimens provided with eight lips and a larger number of tentacles, because we have found sexually mature specimens with no sign of duplication of the mouth lips nor any sign of additional tentacles. Also because we have found that specimens of Octophialucium bigelowi, of approximately the same size taken in the same environment have eight fully developed lips plus additional tentacleless bulbs and ripe gonads at approximately the same umbrella size.

For these reasons we consider that the genus Octocanna is valid and must be revived. It is re- presented by three species that may easily be mistaken with others belonging to the genus Octophialucium. The three species are: Octocanna octonema Haeckel 1879; $O$. polynema Haeckel 1879 and $O$. haeckeli sp. $\mathrm{n}$.

\section{KEY TO THE SPECIES OF OCTOCANNA}

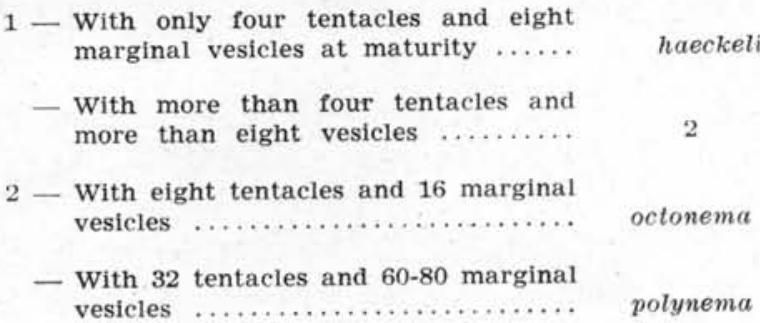

\section{Octophialucium bigelowi Kramp 1955}

(Figs. 5, 6, 7)

Material - Two specimens from samples E307 and E317. The samples were taken at Station 1. Sample 307 was taken April 28, 1960 over $28 \mathrm{~m}$ depth, with Hensen net, vertical haul from $25 \mathrm{~m}$ to the surface; water column homogeneous coastal water mass, with salinity ranging $33.28-34.73 \%$ and temperature $24.5^{\circ} \mathrm{C}$. Sample 317 was taken May 9, 1960 with a Clarke-Bumpus sampler, towed near the bottom in the shelf water mass with $35.5 \%$ salinity and $23.2^{\circ} \mathrm{C}$ temperature. At the same station the same day, the Hensen net fished a specimen of Octocanna haeckeli.

Distribution - Acapulco, on the Pacific coast of Mexico, is the only previous record of this species (Bigelow 1909, p. 169). The present finding is a new record and suggests that this species has an amphiamerican distribution, since it may be found on the eastern and western sides of the American continent, in warm waters.

Description - Bell nearly spherical; 3.5 to $4.5 \mathrm{~mm}$ high; 3.7 to $4.5 \mathrm{~mm}$ wide. Apex rounded, dome-like. Jelly very thick. Eight radial canals arise separately from the periphery of the stomach. Stomach wide and flat. Mouth with eight pointed lips. The manubrium does not extend beyond the umbrella margin. The subumbrella cavity occupies about half or less than half of the umbrella height. The umbrella margin bears eight bulbs with tentacles. Between two successive bulbs there are three marginal vesicles and one rudimentary bulb. The specimens described by Bigelow (1909) have three to five marginal vesicles, one to three rudimentary bulbs, and the umbrella is $8 \mathrm{~mm}$ wide and $10 \mathrm{~mm}$ high. In these specimens the total number of marginal structures is smaller but it is within the limits given in the diagnosis of the species; the size of the umbrella is also smaller in the Brazilian specimens. There are eight gonads in the distal end of the proximal third of each radial canal. Excretory pores are present on very small adradial papillae. 
The number of lips and of marginal structures is twice or more than twice as great as that of Octo. canna haeckeli of same size with which it is apparently very similar.

Discussion - This species was fully described and figured by Bigelow (1909, p. 169) and later redescribed and discussed by Kramp (1955, p. 259) when he established and defined the genus Octo. phialucium for the medusae of the family Phialuciidae with eight radial canals and no ocelli. The presence of eight lips differentiates it from Octocanna, a genus here revived, which has only four mouth lips, eight radial canals and no ocelli.

One of us had the opportunity to study all the specimens stored at the British Museum and could verify that Octophialucium medium Kramp 1955 from the Discovery Collection (st. 282), O. aphrodite (Bigelow 1919) from the Discovery Collections (st. 1574) and from Samarang and some specimens described by BROwne from Ceylon in 1905 as Octo. canna polynema really have eight lips and therefore belong to the genus Octophialucium which may be a good genus in its own right.

\section{GENERAL DISCUSSION}

Within the family Phialuciidae there are two closely related genera, Octocanna Haeckel 1879 and Octophialucium Kramp 1955. Both show eight canals, adaxial excretory papillae, no ocelli, eight gonads completely surrounding the radial canals and separated from the stomach. However the first has only four mouth lips while Octophialucium has eight.

Two species, namely Octocanna haeckeli and Octophialucium bigelowi are very similar and at first glance unrecognizable. However, as described above, they differ in some very definite and important points such as number of lips, number of marginal tentacles, marginal bulbs and marginal vesicles. Specimens of the two species were taken at the same fixed stations at approximately the same time of the same year (May-June the first and AprilMay the second, in 1960), in the same water mass, under similar environmental conditions. All specimens had gonads and most were mature. Considering such coincidences we believe that the two are really distinct species and discard the idea of one being a developmental stage of the other reaching maturity at an earlier stage due to environmental conditions. We also discard the possibility of the four lipped medusae being abnormal specimens because all the four lipped specimens have consistently different numbers and arrangement of the marginal structures.

Two specimens, one of Octocanna haeckeli and one of Octophialucium bigelowi were donated to the British Museum (Nat. History).
We consider it very fortunate to have collected. such similar species together and to have thus been able to clarify a rather complicated systematic problem.

\section{R E S U MO}

Descreve-se uma nova espécie de hidromedusa, coletada em águas costeiras próximas a Santos, pertencente ao gênero Octocanna Haeckel 1879. Este gênero foi considerado obsoleto por KRAMP, mas o achado presente mostra que deve ser reestabelecido. A nova espécie chamada Otocanna haeckeli pertence à família Phialuciidae. Difere das outras duas espécies do mesmo gênero por ser menor, ter umbrela alta em forma de domo, 4 tentáculos, 8 bulbos e 8 vesículas marginais quando atinge a maturidade sexual. A validade do gênero Octocanna fica restabelecida para as Phialuciidae com 8 canais radiais, 8 gônadas, 4 ou mais tentáculos e nunca mais do que 4 lábios.

O gênero Octophialucium Kramp 1955 é mantido como válido para Phialuciidae com 8 canais radiais, 8 gônadas e 8 lábios. Na mesma série de amostras foram coletados alguns espécimes de Octophialucium bigelowi Kramp 1955 que se assemelham à primeira vista a Octocanna haeckeli, mas têm 8 lábios, 8 tentáculos, bulbos rudimentares e um número maior de vesículas marginais quando sexualmente maduros. Ambas as espécies atingem a maturidade com aproximadamente o mesmo tamanho e foram coletadas na mesma massa d'água, em datas próximas do mesmo ano.

\section{ACKNOWLEDGEMENTS}

Sincere thanks are due to Dr. W. J. Rees for the facilities and help offered during a short visit of one of us to the British Museum (Nat. Hist.) and for reading the manuscript critically. Thanks are also due to Miss Leko Kanno and Mr. O. de Fiore for making the drawings.

\section{REFERENCES}

BigeLoW, H. B.

1909. Rep. Sci. Res. Exped. Eastern Tropical Pacific U.S. Fish Comm. St. 'Albatross' 1904/1905. XVI - Medusae, Mem. Mus. comp. Zool. Harv., vol. 37, p. 1-243.

HAECKEL, E.

1879. Das System der Medusen. Erster Theil einer Monographie der Medusen. Jena, 1880. $360 \mathrm{p}$.

Kramp, P. L.

1955. The medusae of the tropical West coast of Africa. Atlantide Rep., n. ${ }^{\circ} 3$, p. 239324.

1959. The Hydromedusae of the Atlantic Ocean and adjacent waters. Dana Rep., n. ${ }^{\circ}$ 46 , p. $1-283$. 

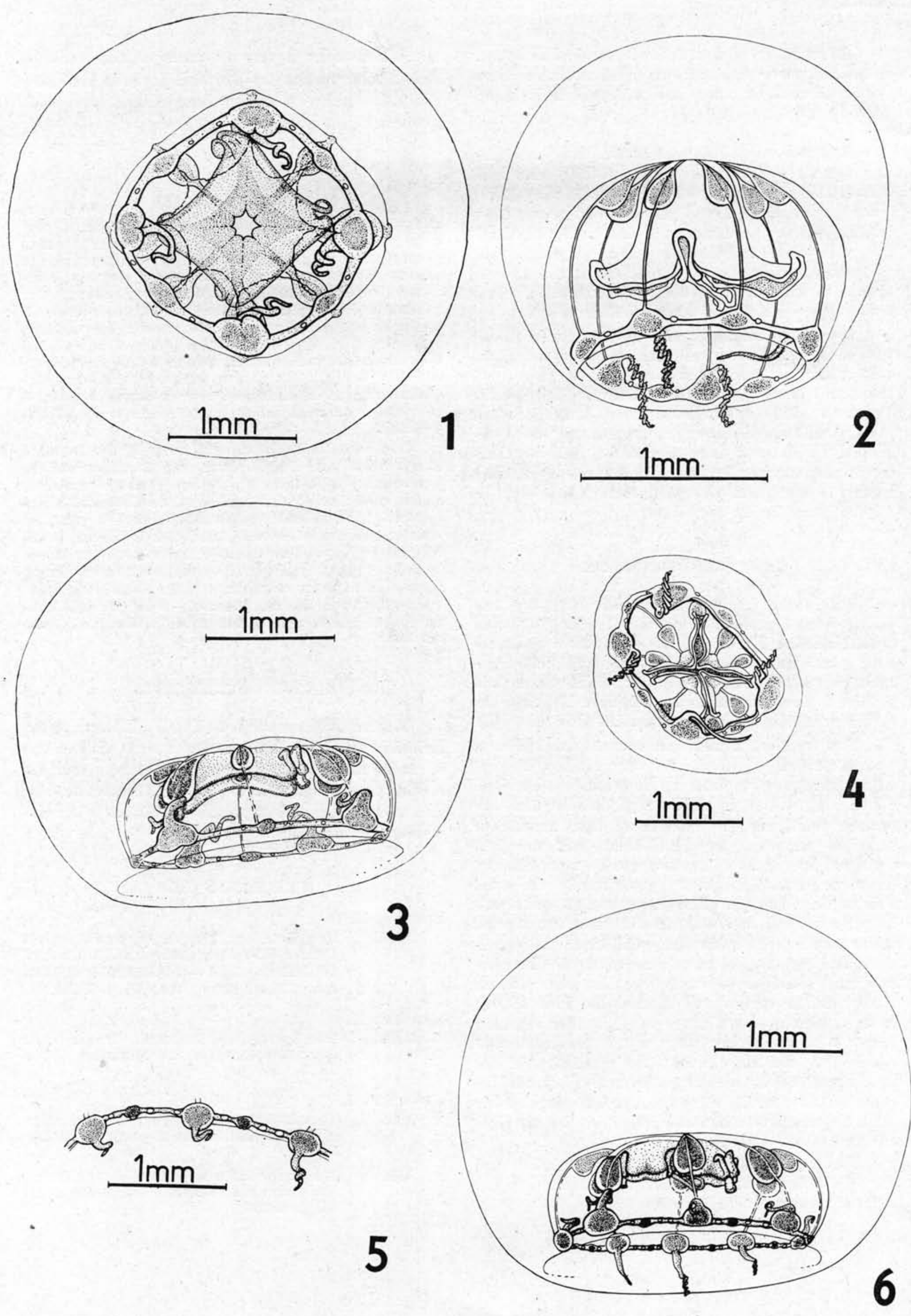


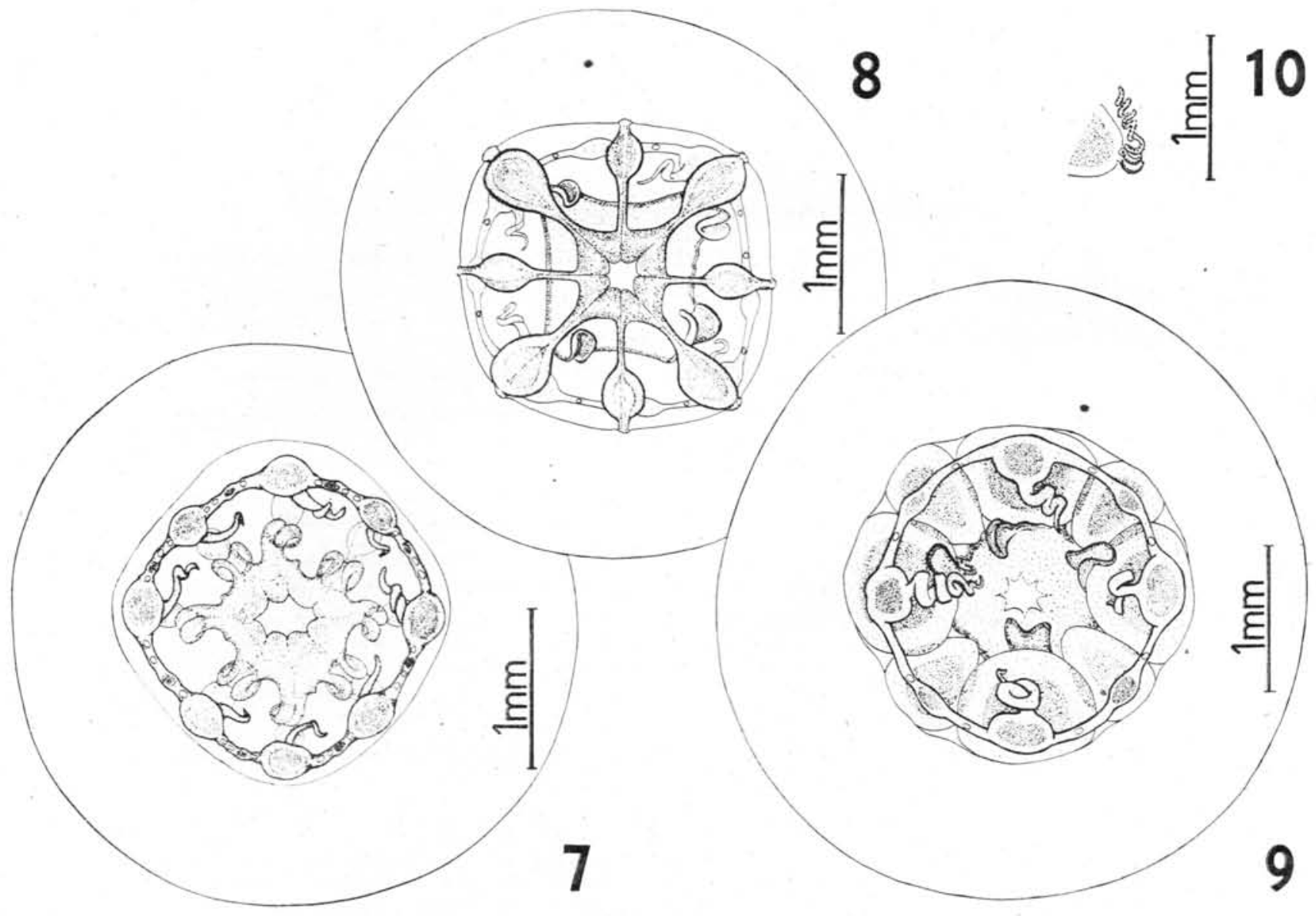

EXPLANATION OF THE FIGURES

Fig. 1 - Octocanna haeckeli sp. n., oral view, mouth gaping, the four lips fully distended.

Fig. 2 - Octocanna haeckeli sp. n., side wiev. Four tentacles and four lips clear shown.

Fig. 3 - Octocanna haeckeli sp. n., specimen larger than the one show in Fig. 2 side view.

Fig. 4 - Octocanna haeckeli sp. n., oral view, mouth closed.

Fig. 5 - Octophialucium bigelowi Kramp 1955, portion of margin.

Fig. 6 - Octophialucium bigelowi Kramp 1955, side view. Eight tentacles and eight lips clearly seen.

Fig. 7 - Octophialucium bigelowi Kramp 1955, oral view, mouth gaping.

Fig. 8-Octocanna haeckeli sp. n. Seen from aboral end.

Fig. 9-Fully mature Octocanna haeckeli sp. n. Seen from oral pole.

Fig. 10 - Marginal bulb and tentacle of Octocanna haeckeli sp. n. 